\title{
Analysis of the Capital Composition for Yacht Industry in China
}

\author{
Li-Feng WANG ${ }^{1, a}$, Chao-Yu ZHENG ${ }^{2, b}$, Wu CHEN ${ }^{2, c, *}$ \\ ${ }^{1}$ School of Business Administration, Jimei University, \\ Xiamen City 361021, Fujian Province, China \\ ${ }^{2}$ School of Marine Engineering, Jimei University, \\ Xiamen City 361021, Fujian Province, China
}

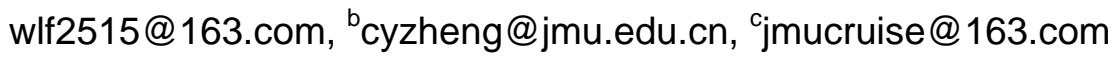

\begin{abstract}
Keywords: Yacht industry, Financial capital, Intellectual capital, Problem and challenge.
\end{abstract}
\begin{abstract}
Since the yacht industry was incorporated into the National Encouragement Industry Catalogue in 2009, through nearly 10 years development, Chinese yacht production capacity has been ranked the top ten in the world, and more than 2/3 of the first-tier cities have put the development of yacht economy into the government planning. While the rapid development of yacht industry has brought economic benefits, it also highlights more and more problems. Therefore, this paper discusses the capital composition of yacht industry on the base of capital construction, analyzes the challenge and problem for the capital of yacht industry existing in China, which would provide good reference for the way to achieve yacht capital preservation and appreciation.
\end{abstract}

\section{Introduction}

Yacht consumption, originated in Britain in the eighteenth Century, was a symbol of the status and identity of the Western upper class society. With the development of the world economy, yacht sports, as a healthy leisure project integrating sports, entertainment and tourism, has entered the public view, and yacht consumption has gradually become popular. Matched by economic means yacht research and development, the general term for a range of economic activities related to yacht design and manufacturing, consumption, maintenance and management, as a new kind of industry form began to receive more and more attention. According to international experience, when per capita GDP reached 3,000 U.S. dollars, it was the embryonic stage of the yacht economy. China's per capita GDP exceeded 3000 U.S. dollars in 2008, and the economic foundation for the development of the yacht industry has been formed. In 2009, the state incorporated cruise yachts into the national encouraged industry category and gives guidance for development of yacht industry. In the past ten years of development, several major yacht industry development areas have been gradually formed, including Shanghai, Sanya, Qingdao Dalian, Xiamen, and the Pearl River Delta. Domestic experts and scholars also attach great importance to the development of the yacht industry. The research field covers the system construction, strategic planning, industrial chain extension, and regional development of the yacht industry. It rarely touches the capital composition and value creation of the yacht industry. The author took this as an opportunity to start with capital preservation and appreciation, explore the bottleneck of the development of the yacht industry, and use the capital preservation and appreciation of the yacht industry as a means to promote the stable and rapid development of the entire industry.

\section{Capital Composition and Value Formation of Yacht Industry}

In 1980s, the field of economic management research scholars put forward intellectual capital management said, understanding of capital from traditional monetary or financial capital to human capital, structural capital, knowledge capital and other fields, a character of this capital is not a physical form, and can give the enterprise value itself bring economic benefits, the value attribute with the monetary capital, are collectively referred to as intellectual capital. The scope of intellectual capital is very wide. The US Financial Accounting Standards Committee (FASB, 2001) classifies technology, customers, market, labor, contract, organization and statutory basic assets into intellectual capital category [1]. As shown in Fig.1, the Scandinavian intellectual capital model 
makes a good description of the capital structure of the firm [2]. Industry is a collection of economic activities of enterprises have some similar attributes, the same can be understood as the combination of financial capital and intellectual capital, which is the financial capital in the form of monetary capital and its transformation to enhance the overall value of the industry by increasing the value of the function of capital; Intellectual capital achieves the purpose of value preservation and value increase through value creation and value extraction, which promotes the absolute growth and structural optimization of the total industrial economy and achieves the purpose of industrial development.

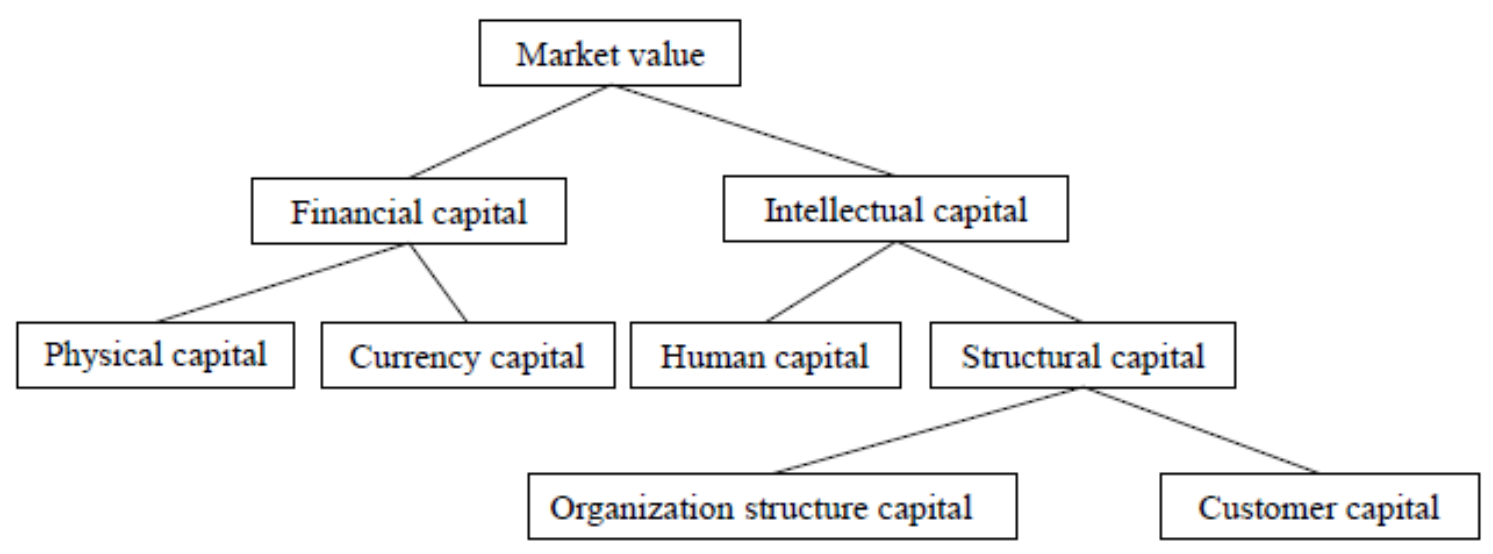

Fig.1. Structure model for the market value

\section{Financial Capital of Yacht Industry}

The financial capital from the perspective of the enterprise can be understood as the asset in the company's balance sheet because it pursues the maximization of the shareholder's wealth (or the maximization of the value of the company). The capital preservation and appreciation rate index uses the end-of-year owner's equity and the equity at the beginning of the year to compare it. It explains the security and return of shareholders' investment in capital during the year. If we put the financial capital here into the yacht industry, it includes the monetary capital, production capital and commodity capital circulating in the entire yacht industry chain. With reference to the understanding of corporate financial capital, it is the flow of all enterprises and non-current asset items in the entire yacht industry. Different from a single enterprise, the industrial sector is an important component of the national economy. It cannot consider only the interests of shareholders. Therefore, it should expand the scope of its capital preservation and value increase from industrial capital to financial capital. The output value is the total value of the final products and services produced by capital input. It is the output of all capital inputs in the industry. Although it represents a certain amount of double-counting in the total capital of the yacht industry, it is calculated by dividing the output value of the yacht industry by the end of the year by the beginning of the year. The dynamic relative value of the yacht industry's output value calculation can eliminate the effects of double counting, reflecting the development of the yacht industry in a certain period of time, which indirectly reflects the capital preservation and appreciation of the yacht industry.

\section{Intellectual Capital of Yacht Industry}

The realization of customer value is the result of the interaction between human capital and structural capital, and it is also a direct expression of the realization of the value of intellectual capital in the industry [3-4]. The human capital of the yacht industry refers to the personal ability, knowledge, skills, and experience of the yacht industry employees. From the yacht design, manufacturing, exhibition, repair, maintenance, to consumption, and other related industries, the yacht industry needs a variety of professionals. The particularity of yacht products and consumption determines unique requirements in the aspects of design, sales, management, etc. The specificity of yacht industry professionals is very demanding, and training is not easy. The development of the yacht industry 
requires adequate reserve of yacht professionals. In addition, the attitude, quality, and efficiency of human capital also determine the development of the yacht industry. The attitude or value of human capital is the action criterion of human capital, which determines the direction of the human capital yacht business and the future of the yacht industry; The quality of human capital determines the value creation ability of the yacht industry and expands the capital appreciation space of the yacht industry; The efficiency of human capital determines the output level of the yacht industry and which is the guarantee of the scale of the yacht industry output value.

The organizational structure capital refers to the knowledge platform, information technology support system, business application system, organizational structure, intellectual property, corporate image, etc. It is the support and infrastructure for human capital. The organizational structure capital of the yacht industry in the yacht industry is only part of the yacht's organizational structure capital. It should also include yacht industry policies, upgrading of industrial structure and industrial chain, yacht industry regional planning, etc .Taking into account the peculiarities of the yacht industry, special industrial planning such as yacht navigation route and tourism leisure water area planning and marina berth planning is not only a part of the capital structure of the yacht industry, but also a constraint variable for the development of the yacht industry. These organizational structure capitals can be regarded as the working methods and processes accumulated by long-term knowledge investment in the human capital of the yacht industry. Efficient organizational structure capital can effectively improve the internal cost, quality, service and speed of the industry, and increase the overall performance and value of the industry.

The customer capital in the micro field is the relationship capital accumulated between the company and customers, suppliers, and partners, and it is the channel or relationship value that the company develops in the business process. The introduction of customer capital into the area of the meso field for the industry, the customer capital of the yacht industry should include the associated industry sectors such as government, consumers, and suppliers associated with the yacht industry and the value of relationships that can be identified by the public. The customer capital of the yacht industry focuses on the periphery of the industry and can be said to be the starting point of the capital chain and knowledge chain of the yacht industry. The rise of the yacht industry originated from the attention of various customers (that is to say the accumulation of initial customer capital). The industry increased customer satisfaction by satisfying customer needs and achieving customer value. The improvement of customer satisfaction also promoted the further development of the yacht industry.

It can thus be seen that, fundamentally speaking, the development of the yacht industry is the first to achieve the value-added and increase of the financial capital and intellectual capital in the industry. Any shortage of capital investment will directly affect the realization of industrial value, and thus affect the future development of the entire yacht industry.

\section{Challenge and Problem of the Capital of Yacht Industry}

Good development opportunities brought about the rapid development of yacht industry. By the end of 2013, Chinese overall yacht production capacity was among the top ten in the world, among the 36 first-tier cities, more than $2 / 3$ of the cities have launched economic activities related to yacht industry, and products and services provided by yacht industry have become the star products of coastal tourism. At the same time, it should be noted that the software and hardware environment of the yacht industry development is still not mature enough, and the capital weakness is obvious.

\section{Small Scale for Yacht Industry}

The current scale of the yacht industry highlights the weak financial capital of the industry. Taking the Xiamen city as an example, being the second "Yacht Sailing Industry Development Test Base" in China, Xiamen ranked first in China's yacht city competitiveness in the "2012-2013 China Yacht Industry Report" assessment. The data of Xiamen yacht industry can reflect the capital strength of China's yacht industry to some extent. In 2016, there were a total of 203 yacht enterprises registered in Xiamen, 26 ship-maintenance and boat-supporting equipment companies, 31 yacht clubs 
registered by the Fujian Maritime Safety Administration, and direct economic output value of the yacht industry of 802 million Yuan. The economic scale of linkage economy was nearly 80 million Yuan. It is still in a weak position in the national economy for Xiamen; it is still in a weak position in the Xiamen national economy. In the same year, Xiamen had only 455 yachts sailing in the number of sailing yacht harbor, including 208 power boats and 247 sailing boats. The number of boats is still far from saturation. The scale results in benefits and the output indicators of the yacht industry are not satisfactory. The reason behind this is that the existing capital stock and input of the industry are limited, it is difficult to form economies of scale, and the basis for industrial development is weak.

\section{Deficient Human Capital for Yacht Industry}

The human capital of the yacht industry is scarce. The lack of human capital is reflected in both quantity and quality. From the quantitative point of view, some scholars have estimated that the gap between yacht design and manufacturing professionals in China at least 50,000.If the related areas such as yacht marketing, maintenance, terminal club management, training and education are also counted, the gap for professionals will increase to 200,000.From a qualitative point of view, there is no professional education that matches the yacht industry in China's universities or is in its infancy. Yachts R\&D and design talents have changed from other majors, and it is difficult to form a unified yacht technology, craft and art, high-level yacht designers are extremely scarce. The personnel training management system in the yacht industry is immature, and the technical-type production personnel are severely inadequate. As a result, many yacht companies are lagging behind in process and have limited production capacity, and are unable to cope with the needs of the current international market. Other industry support staffs also grew slowly due to the lack of systematic training in yacht expertise and were unable to keep pace with the rapid development of the yacht industry. The shortage of human capital in the yacht industry has severely restricted the formation of industrial innovation capabilities and has become a major bottleneck in the expansion of industrial profit margins.

\section{Slow Accumulation of Capital from Organizational Structure}

The accumulation of capital from the organizational structure of the yacht industry is slow. At the institutional level, since 2008, many yacht industry development policies have been introduced from the national to the local. From the perspective of the departments involved, there are the Ministry of Transport, the Ministry of Finance, the Ministry of Industry and Information Technology, the National Tourism Administration, etc. The yacht industry does not have a clear oversight of the competent authorities. Each department is in its own right, and some business management is absent. For example, the access mechanism for the maritime tourism market, yacht charter, and yacht route planning are all not explicitly stated or mixed with other ship policies. In terms of industrial structure, the development of the yacht industry in most regions is still in the second industry stage. At present, China has formed the Bohai Bay, the Yangtze River Delta and the Pan-Pearl River Delta yacht three major production bases. The development of high-end yacht service industry is still in its infancy. It mainly focuses on the hosting of some exhibitions and competitions. The yacht consumption mainly focuses on private leisure or business exchanges. The functions of sailing, sports, entertainment and leisure are not fully reflected. The channels for the popularization of yacht consumption are not completely open. In addition, the infrastructure and platform construction of the yacht industry is far from the actual needs. The setting up of special open ports for yachts, the planning of public terminals, the division of land and water function areas, and the construction of safeguard operation and maintenance systems and management information platforms cannot meet the needs of the market. Missing yacht industry organization capital is currently China's yacht industry walk in the low-end chain, optimize the industrial structure is not the main reason.

\section{Narrow Definition of Customer Capital}

The definition of customer capital in the yacht industry is too narrow. The traditional wisdom is that consumption is a luxury yacht, its consumer groups to the wealthy elite class. After the introduction of the yacht project into China, people continued this perception, leading the government and 
companies to consider more issues regarding the manufacture, sale and use of yachts when formulating relevant policies and business strategies, rather than the development and support of yacht-related service functions. The current definition of yachts in the "Safety Management Regulations for Yachts" is just a vessel equipped with a mechanical propulsion power system used by yacht owners for sightseeing, recreational activities and other activities. The right to use a yacht is in the hands of all people. Other actors who have relevant qualifications cannot use the yacht by any means. This is equivalent to closing the possibility of ordinary people engaging in yachting. The unity of yacht ownership and use rights eliminates the possibility of yacht rental. It is high price limits the consumer groups can only be wealthy class, many funds and people want to enter the yacht industry has no way to go. Yacht industry development depends infrastructure can only rely on the government, business groups or individual investment club, and unable to meet the needs of rapid development of the yacht industry. The error of yacht consumption concept has made the development of the yacht industry in China long-term limited to the manufacturing industry. And the customer capital existing in the high-end service industry of yachts has not yet been fully developed, which greatly limits the scale of development of the yacht industry.

\section{Summary}

The healthy development of the yacht industry is the result of the maintenance and appreciation of industrial capital. Studying the capital composition of the yacht industry can clarify the ways in which various types of capital can be maintained and appreciated, and the factors that restrict the development of the industry can be found and solved. In the analysis of this article, it can be found that the total financial capital of the yacht industry is small, which limits the scale development of the yacht industry; and the shortage of intellectual capital reserves inhibits the value-added space of the yacht industry. The analysis results could help conduct the future research on the ways to achieve yacht capital preservation and appreciation.

\section{Acknowledgement}

This research was financially supported by the High-level Technical Talent Training Project for Transportation Industry in China.

\section{References}

[1] FASB. Getting a Grip on Intangible Assets-What They Are, Why They Matter, and Who should be Managing Them in Your Organization [J]. Harvard Management Update, 2001, 6 (2):6-8.

[2] D.W. Li. Improving Corporate Value: Value Creation of Intellectual Capital Based on Knowledge Value Chain [M]. Chengdu: Southwest Jiaotong University Press, 2012, (2):49-53.

[3] W. Zhong. 100 Billion Yacht Industry into a Policy Sensitive Period Difficult Self-help. China Enterprise News, 2015-2-14.

[4] P. Sullivan. Intellectual Capital Management-The Core Competence of Enterprise Value Extraction [M]. Beijing: Intellectual Property Publishing House, 2002, (6):21-22. 